Сидоренко Наталя Олегівна кандидат наук 3 державного управління, доцент кафедри менеджменту, Інститут підготовки кадрів Державної служби зайнятості України, вул. Нововокзальна, 17, м. Київ, 03038, тел.: (044) 536-14-85, e-mail: sidnat@ukr.net, https://orcid.org/0000-0001-8734-9704

\title{
МЕТОДИКА ОЦІНКИ ЯКОСТІ НАДАННЯ АДМІНІСТРАТИВНИХ ПОСЛУГ НА МІСЦЕВОМУ РІВНІ
}

Анотація. Стаття присвячена дослідженню особливостей оцінювання якості надання адміністративних послуг органами місцевого самоврядування в Україні. Встановлено, що критеріями оцінювання якості надання адміністративних послуг вважаються ознаки, що формують ступінь задоволення інтересів i запитів клієнтів, які є споживачами адміністративних послуг, професійний рівень роботи органів, які надають адміністративні послуги, котрі мають забезпечуватися, базуючись на таких вимогах, як ефективність, вчасність, доступність, зручність, прозорість, повага до людини, фаховість. Наведено методи оцінювання, що використовуються при управлінні якістю адміністративної послуги. 3'ясовано, що важливою частиною оцінки якості адміністративних послуг для громадян вважається напрацювання і реалізація автоматизованої системи електронних послуг. Внаслідок формування зазначених послуг територіальні громади забезпечили економію власного часу й ресурсів. Наголошено на тому, що виконання оцінки якості надання адміністративних послуг має скеровуватися на сучасний вид адміністративних послуг - «єдине вікно». Подібна форма адміністративних послуг репрезентована Центрами надання адміністративних послуг. В аспекті зазначених адміністративних послуг актуальним вважається застосування громадського контролю як одного 3 результативних механізмів покращення та виправлення недоліків у наданні адміністративних послуг. Наведено критерії оцінки якості надання адміністративних послуг, які варто враховувати під час здійснення. Встановлено, що на даний час немає конкретно встановлених меж критеріїв якості надання адміністративних послуг, в результаті чого зумовлюється недостатня результативність роботи місцевих органів влади. Зазначено, що введення системи оцінки критеріїв якості надання адміністративних послуг - це один із дієвих способів покращення ефективності органів місцевого самоврядування. З'ясовано, що щоб успішно впровадити процедури стосовно формулювання оцінки та якості надання адміністративних 
послуг, повинні існувати конкретно окреслені умови та алгоритм дій під час оцінки надання адміністративної послуги.

Ключові слова: адміністративні послуги, місцеві органи влади, органи місцевого самоврядування, оцінка якості надання адміністративних послуг, громадський контроль, критерії якості надання адміністративних послуг.

Sydorenko Natalya Olehivna Candidate of Sciences in Public Administration, Associate Professor of the Management Department, Institute of Personnel Training of the State Employment Service of Ukraine, Novovokzalna St., 17, Kyiv, 03038, tel.: (044) 536-14-85, e-mail: sidnat@ukr.net, https://orcid.org/0000-0001-8734-9704

\title{
METHODS OF ASSESSING THE QUALITY OF PROVISION OF ADMINISTRATIVE SERVICES AT THE LOCAL LEVEL
}

\begin{abstract}
The article is devoted to the study of the peculiarities of assessing the quality of administrative services provided by local governments in Ukraine. It is established that the criteria for assessing the quality of administrative services are signs that form the degree of satisfaction of interests and requests of customers who are consumers of administrative services, the professional level of bodies providing administrative services, which should be provided based on requirements such as efficiency, timeliness, accessibility, convenience, transparency, respect for the person, professionalism. The evaluation methods used in the quality management of administrative services are given. It was found that an important part of assessing the quality of administrative services for citizens is the development and implementation of an automated system of electronic services. As a result of the formation of these services, local communities have saved their own time and resources. It is emphasized that the assessment of the quality of administrative services should be aimed at the modern type of administrative services - "single window". This form of administrative services is represented by the Centers for Administrative Services. In the aspect of these administrative services, the use of public control is considered relevant as one of the effective mechanisms for improving and correcting shortcomings in the provision of administrative services. The criteria for assessing the quality of administrative services that should be taken into account during implementation are presented. It is established that at present there are no specifically defined limits on the quality of administrative services, resulting in insufficient performance of local authorities. It is noted that the introduction of a system for assessing the quality of administrative services is one of the effective ways to improve the efficiency of local governments. It was found that in order to successfully implement procedures for formulating the assessment and quality of administrative services, there must be specific conditions and
\end{abstract}


algorithms for action when evaluating the provision of administrative services.

Keywords: administrative services, local authorities, local governments, quality assessment of administrative services, public control, quality criteria for administrative services.

\section{Постановка проблеми. В Україні останніми роками надання} адміністративних послуг вважається одним із пріоритетних напрямків діяльності місцевих органів влади. Впродовж нетривалого часу було організовано більше 600 центрів надання адміністративних послуг (ЦНАП). В значній частині органів влади, переважно в обласних центрах і містах обласного значення, дійсно покращилася якість послуг, що надають за допомогою ЦНАП. Один із головних факторів механізму організації дієвих центрів надання адміністративних послуг $\mathrm{i}$ зростання якості надання адміністративних послуг - це власне зацікавлення керівників органів місцевого самоврядування. Щоб визначити реальну ситуацію в секторі надання послуг, потрібно регулярно здійснювати їі оцінку. Зважаючи на це, набуває актуальності введення в практику органів влади результативних методів здійснення контролювання й моніторингу якості надання послуг. Важливо, щоб зазначені заходи проводилися комплексно та регулярно, а не відповідно до ситуації чи несистематично. Головним фактором вважається утворення такої системи здійснення оцінки, котра б охоплювала не один механізм та під час котрої до оцінки приєднувалися б усі, хто зацікавлений в ній, зокрема громадські організації та громадські активісти, органи місцевої, районної та обласної влади, незалежні фахівці. Дієва система оцінювання дозволить отримувати об'єктивні відомості стосовно якості надання послуг; крім того, така система може бути передумовою для нагального прийняття управлінських рішень для справжнього покращення й наближення рівня якості послуг відповідно до запитів клієнтів.

Аналіз останніх досліджень і публікацій. Дослідженням особливостей надання адміністративних послуг органами місцевого самоврядування в Україні займалися такі науковці як О. Бабінова, І. Бригілевич, Т. Буренко, Л. Гудима, А. Смець, Ю. Жук, В. Занфіров, О. Карий, Ю. Кириченко, Т. Маматова, І. Огірко, К. Процак, А. Серант, В. Тимощук та інші.

Мета статті полягає у проведенні дослідження особливостей оцінювання якості надання адміністративних послуг органами місцевого самоврядування в Україні.

Виклад основного матеріалу. Реформа децентралізації в Україні, що характеризується передачею владних повноважень й фінансів від органів центральної виконавчої влади до органів місцевого самоврядування, активно триває в Україні з 2015 року. Саме це створює нові можливості на 
муніципальному рівні навіть для малих міст, сіл, селищ та невеликих громад задля їх подальшого розвитку. Завдяки процесу об'єднання новоутворені громади мають можливість поєднати власні ресурси для того, щоб самостійно вирішувати питання місцевого значення, підвищувати якість життя і нести за це відповідальність. Одним 3 напрямів реалізації самоврядних повноважень на локальному рівні $\epsilon$ розбудова сфери надання адміністративних послуг населенню шляхом створення належних Центрів надання адміністративних послуг (ЦНАП) [10, с. 166].

Варто наголосити на тому, що адміністративні послуги - це ті публічні (тобто державні та муніципальні) послуги, що надаються органами виконавчої влади, виконавчими органами місцевого самоврядування та іншими уповноваженими суб'єктами, і надання яких пов'язане з реалізацією владних повноважень. Враховуючи те, що адміністративні послуги, по-перше, за характером діï $\epsilon$ юридично i соціально значущими, по-друге, за суб'єктом одержання послуги надаються фізичним та юридичним особам, вони є видом публічних послуг. Водночас адміністративні послуги можуть бути державними, якщо надаються органами виконавчої влади за кошти державного бюджету, та муніципальними, якщо надаються органами місцевого самоврядування за кошти місцевого бюджету [8].

Органи місцевого самоврядування максимально наближені до громадян й несуть пряму відповідальність за якість послуг, які їм надають. Отже, головною їхньою ціллю стосовно громадян повинне стати надання якісних послуг 3 оптимізованими видатками за умови відкритого функціонування й чітко визначеної відповідальності.

Варто зазначити, що існують певні виклики у наданні адміністративних послуг з точки зору органів місцевого самоврядування. На першому місці традиційно виділяють брак фінансових, матеріальних, кадрових ресурсів для належної організації надання адміністративних послуг. Серед іншого, у муніципальному секторі це пов'язано 3 тим, що абсолютна більшість муніципальних адміністративних послуг є безоплатними для замовників. Цю причину треба усувати, запроваджуючи хоча б частково компенсаторні розміри адміністративних зборів. Також викликами для органів місцевого самоврядування є недостатньо узгоджене законодавство, в тому числі покладення обов’язків 3 виконання делегованих державних повноважень без фінансового забезпечення, брак методологічного супроводу при впровадженні новацій та навіть недостатність конструктивної співпраці 3 боку окремих центральних органів виконавчої влади (як-от, у 2014 році з боку Державної міграційної служби). Особливо це стало відчутно при включенні до надання через центри надання адміністративних послуг так званих «базових» послуг, які де-юре $\epsilon$ компетенцією органів виконавчої влади. Але найбільшою перепоною для 
впровадження змін у сфері адміністративних послуг на місцях є фактор «першої особи», тобто недостатнє розуміння міським головою, іншими керівниками суті проблематики адміністративних послуг і необхідних заходів для зміни ситуації. Як правило, без дієвої підтримки таких осіб позитивних змін досягти неможливо [14].

Ще декілька років тому процедура надання адміністративних послуг органами державної виконавчої влади й органами місцевого самоврядування була ускладненою та недостатньо зрозумілою для іiі споживача. Сьогодні в упорядкуванні та підвищенні якості надання адміністративних послуг та ефективності функціонування органів державної влади та місцевого самоврядування значну роль має відігравати впровадження в діяльність органів влади міжнародних стандартів системи управління якістю. Однак масштабна реформа запровадження цієї системи, що була розпочата у 2006 р. із прийняттям Кабінетом Міністрів України Постанови «Про затвердження Програми запровадження системи управління якістю в органах виконавчої влади» від 11 травня 2006 р. № 614, так і не була реалізована, а Постанова втратила чинність у 2011 p. [9, c. 152].

Загалом ситуація в Україні щодо надання адміністративних послуг поступово змінюється на краще. Розвиток і вдосконалення системи надання адміністративних послуг та формування оптимальної мережі Центрів надання адміністративних послуг є одним з основних пріоритетів процесу децентралізації. Розвиткові мережі ЦНАП сприяє передання більшої кількості повноважень органам місцевого самоврядування щодо надання основних груп послуг, підготовка зручних приміщень і формування належної інфраструктури надання послуг, зокрема в новостворених об'єднаних територіальних громадах, що забезпечує наближення адміністративних послуг до замовників. Важливим у цьому процесі $\epsilon$ участь Міністерства економічного розвитку i торгівлі та Міністерства регіонального розвитку, будівництва та житлово-комунального господарства, які формують державну політику щодо розвитку ЦНАП [2].

Під час децентралізації особливу відповідальність стосовно організації відповідних центрів надання адміністративних послуг покладено на органи місцевого самоврядування. Саме від розуміння та співпраці керівників органу місцевого самоврядування залежить, наскільки позитивним буде результат і чи задоволеними будуть мешканці якістю послуг. Важливе значення в даній справі має напрацювання єдиних підходів та встановлення стандартів відповідного ЦНАП, зокрема якнайширший перелік послуг, доступність та якість надання послуг, погоджена потрібна документація, кваліфіковані кадри, «наближення» послуг до їх споживачів за допомогою організації територіальних підрозділів і віддалених робочих місць. На даний час існують зразки реально здатних центрів надання адміністративних послуг в різних органах місцевого самоврядування - 
не тільки в обласних центрах і містах обласного значення, а й в новостворених об'єднаних територіальних громадах.

Попри те, що чимало органів місцевого самоврядування уже пройшли етап створення ЦНАП, потреба вдосконалення для багатьох із них залишається досить актуальною. Для реального виявлення якості надання адміністративних послуг i діяльності ЦНАП необхідно періодично проводити їх оцінювання та самооцінювання. Важливо, щоб ця діяльність була систематичною, грунтувалася на випробуваній методології, охоплювала декілька інструментів оцінювання та залучала всі зацікавлені сторони: громадських активістів, громадські організації, органи місцевої, районної й обласної влади, незалежних експертів [2].

Процеси здійснення реформи місцевого самоврядування та територіальної організації влади створили передумови щодо затвердження нормативних актів, норми яких спрямовані на розширення повноважень органів місцевого самоврядування у сфері надання адміністративних послуг. Станом на сьогодні через ЦНАП надається великий перелік послуг, які умовно можна поділити на наступні групи: державна реєстрацію речових прав на нерухоме майно та їх обтяжень; дозвільного характеру; державна реєстрація юридичних осіб, фізичних осіб - підприємців та громадських формувань; нотаріальні; соціального характеру; місцеві; послуги з реєстрації місця проживання особи; послуги у сфері державної реєстрації актів цивільного стану; паспортні та інші [10, с. 167].

Надання якісних адміністративних послуг органами місцевого самоврядування в контексті підвищення довіри населення до них та зменшення соціального напруження виступає вагомим чинником, що характеризує ефективність місцевого управління. Задоволеність споживача та орієнтація на споживача мають бути основними принципами під час визначення критеріїв оцінювання якості надання адміністративних послуг. Відтак, оцінювання якості надання адміністративних послуг $є$ перевіркою діяльності адміністративного органу щодо надання адміністративних послуг, зокрема результату такої діяльності, на відповідність офіційно встановленим вимогам або очікуванням споживачів [7, с. 36].

Щоб мати можливість здійснювати оцінку якості надання адміністративних послуг та уніфікувати їхнє надання, потрібно окреслити критерії оцінки якості надання адміністративних послуг. Критеріями оцінювання якості надання адміністративних послуг вважаються ознаки, що формують ступінь задоволення інтересів і запитів клієнтів, які $\epsilon$ споживачами адміністративних послуг, професійний рівень роботи органів, які надають адміністративні послуги, котрі мають забезпечуватися, базуючись на таких вимогах, як ефективність, вчасність, доступність, зручність, прозорість, повага до людини, фаховість.

Принципово важливе призначення критерію полягає у тому, що він $є$ 
основою для визначення одного або кількох стандартів надання адміністративних послуг. Здійснення оцінювання якості надання адміністративних послуг може визначатися 3 погляду держави (внутрішнє оцінювання органу) та споживачів (зовнішне оцінювання). Крім того, можна виокремити «змішане» оцінювання, яке здійснює зовнішній суб'єкт, що не $є$ споживачем, а швидше за все «відповідальним надавачем» послуги [1].

Задоволення клієнта й націленість на клієнта повинні стати головним критерієм у процесі окреслення принципів оцінки якості надання адміністративних послуг.

Ефективна система оцінювання дасть змогу отримувати об'єктивну інформацію щодо якості надання послуг. Така система може стати основою для оперативного ухвалення управлінських рішень задля реального поліпшення та наближення рівня якості послуг до потреб замовників [2].

Оцінювання адміністративних послуг можливе в процесі діяльності на різних етапах виконання своїх зобов'язань органами державної влади та місцевого самоврядування, а саме:

1) процес здійснення контрольної діяльності органами місцевого самоврядування та державної влади при здійсненні адміністративної послуги в рамках таких процесів, як перевірки, ревізії, інспектування тощо та інша дозвільно-розпорядча діяльність, що не є адміністративними послугами;

2) рівень надання адміністративних послуг та умови забезпечення реалізації адміністративної послуги в основу якої лягають права та свободи громадян;

3) монополізація адміністративної послуги, що може здійснюватися лише в певних населених пунктах або ж вона доступна широкому колу споживачів (наприклад використання електронних сервісів);

4) розмежування адміністративних послуг на основі специфічних потреб територіальної громади залежності від їх географічного, етнографічного, мовного, економічного, соціального, політичного стану [5].

Оцінку результативності надання адміністративної послуги можна здійснити і за допомогою методів оцінювання, що використовуються при управлінні якістю адміністративної послуги [3, с. 102]. Найпоширенішим з них є метод управління за цілями, який полягає в оцінці досягнутих органом місцевого самоврядування та державним службовцем цілей. Серед методів вивчення очікувань споживачів щодо надання послуги та задоволеності наданою послугою можна виділити: анкетування, опитування, інтерв'ювання, тестування тощо, а серед методів поліпшення найвідомішими є бенчмаркінг та реінжиніринг [4].

Основними методами оцінювання якості адміністративних послуг $\epsilon$ визначення експертних середніх значень на основі кількісних та якісних чинників, що окреслюють умови дослідження та випадкові чинники. 
Дослідження впливу тих чи інших чинників на мінливість середніх $є$ задачею дисперсійного аналізу. Дисперсійний аналіз використовує властивість адитивності дисперсії випадкової величини, що обумовлено дією незалежних чинників. Дисперсійний аналіз особливо ефективний під час вивчення кількох чинників. Під час дисперсійного аналізу кожне спостереження служить для одночасної оцінки всіх чинників та їх взаємодії. Також одним з ефективних методів оцінювання якості надання адміністративних послуг на рівні місцевого самоврядування так i центральних органів влади $\epsilon$ методика проведення експертної оцінки, що визначається на таких етапах: 1) окреслення основного напрямку щодо проведення експертних оцінок; 2) визначення програми експертних оцінок: формулювання мети та завдань експертної оцінки; розробка анкети (опитувальника); вибір способу оцінки компетентності експертів; формування правил проведення опитування експертів; формування правил та методів обробки думок експертів; 3) створення групи експертів, що будуть проводити оцінку [13, с. 154].

Важливою частиною оцінки якості адміністративних послуг для громадян вважається напрацювання і реалізація автоматизованої системи електронних послуг. У наслідок формування зазначених послуг територіальні громади забезпечили економію власного часу й ресурсів. До головних переваг системи електронних послуг зараховуються:

1) створення нових організаційно-технологічних видів надання адміністративних послуг місцевим мешканцям, основуючись на особливих рисах прозорості й паритетності для всіх, хто проживає в територіальній громаді;

2) формування електронного документообігу між суб'єктами надання адміністративних послуг населення;

3) надання адміністративних послуг особам за суб'єктами підприємницької діяльності:

- формування профілю в електронному кабінеті клієнта;

- консультування в електронному виді (в рамках встановленої відповідно до законодавства компетенції);

- завчасний запис на прийом до адміністратора Центру надання адміністративних послуг;

- ознайомлення з даними щодо стану справ;

- огляд електронних повідомлень.

Проте введення електронної системи надання адміністративних послуг населенню - це один із сучасних напрямків, що вимагає наступного дослідження й покращення системи оцінювання якості послуг, які одержуватиме населення. На сьогодні $\epsilon$ необхідність чергового покращення критеріїв оцінки, інструментів, що надається клієнтами у виді оцінок. 
Загалом усі критерії надання адміністративних послуг можна поділити на об’єктивні та суб’єктивні. До об’єктивних критеріїв належать, наприклад, кількість ЦНАПів чи адміністративних послуг (повноти переліку), які можуть надавати ЦНАПи, наявність інформаційних стендів у приміщенні ЦНАП. До суб'єктивних критеріїв належать чинники, які можуть неоднаково сприйматися різними споживачами, наприклад, охайність та привітність персоналу, чітке та зрозуміле викладення інформації на стендах ЦНАПів тощо. Щодо якості надання послуг органами місцевого самоврядування, то на це найчастіше впливає брак ресурсів на забезпечення організації надання адміністративних послуг, на підготовку та мотивацію праці кваліфікованих працівників ЦНАПів, на здійснення контролю, на матеріальне забезпечення роботи ЦНАПів (бланки, папір, витрати на поштові відправлення тощо) [8].

В контексті прийняття дієвих управлінських рішень щодо підвищення якості надання адміністративних послуг доцільно відповідну інформацію піддавати інформаційно-аналітичному опрацюванню. Відтак, сьогодні актуальним завданням $€$ створення сучасної інформаційно-аналітичної інфраструктури органів місцевого самоврядування. Від того, наскільки повно буде використана інформація про якість обслуговування громадян, про рівень довіри населення до влади, залежатиме результативність управління. Отже, консолідація інформації у галузі оцінювання якості адміністративних послуг спрямована на якісне інформаційно-аналітичне забезпечення органів місцевого самоврядування 3 метою підтримки прийняття управлінських рішень [4].

Зважаючи на зазначене вище, варто зауважити, що оцінювання якості адміністративних послуг може основуватися на базі оцінки споживачами послуг, оцінки надавачами послуг чи змішаної оцінки, іншими словами, виконується, грунтуючись на формуванні оцінок надавачами та споживачами. Головним завданням покращення та введення нового оцінювання якості адміністративних послуг, які надаються населенню, вважається покращення процесу взаємозв'язків між державними органами влади й населенням.

Подальше удосконалення оцінки якості адміністративних послуг, що надаються державними органами влади мають вдосконалюватися на основі прийнятої в 2014 р. Концепції реформування місцевого самоврядування та територіальної організації влади в Україні. Зокрема серед завдань реформи є ті, що присвячені досліджуваному питанню, як-от:

- територіальної доступності, що передбачає надання послуг на території громади, де проживає особа;

- належної матеріально-технічної бази для надання основних форм адміністративних послуг (органи місцевого самоврядування повинні мати у своєму розпорядженні відповідні приміщення та інфраструктуру); 
- відкритості інформації про послуги, порядок та умови їх надання;

- професійності надання адміністративних послуг [12].

Слід наголосити, що виконання оцінки якості надання адміністративних послуг має скеровуватися на сучасний вид адміністративних послуг - «єдине вікно». Подібна форма адміністративних послуг репрезентована Центрами надання адміністративних послуг.

В Україні вже сформувалась досить вдала практика функціонування ЦНАПів (Центрів надання адміністративних послуг). ЦНАПи працюють на рівні міст, ОТГ та районів і провадять свою діяльність згідно з ЗУ "Про адміністративні послуги" [11]. Розвиток ЦНАПів у різних регіонах належить до сфери відповідальності місцевої влади (міста, селища або села). Від місцевої влади залежить усе, починаючи від ремонту в приміщенні ЦНАП і оснащення, закінчуючи переліком надання безкоштовних адміністративних послуг для зручного очікування (чай/кава, доступ до Інтернету). Ситуація з фінансуванням роботи ЦНАПів найскладнішою $є$ в райдержадміністраціях. Крім того, потребує спрощення процедура надання адміністративних послуг для отримувачів [8].

Завдяки державному та громадському моніторингам якості надання адміністративних послуг було виявлено деякі проблемні аспекти обслуговування громадян у центрах надання адміністративних послуг: невідповідність роботи низки центрів надання адміністративних послуг вимогам Закону України «Про адміністративні послуги», зокрема щодо часу прийому суб'єктів звернень; недостатність інформації та консультування громадян із питань надання послуг у центрах; вимогу додаткових, не передбачених законодавством документів для надання адміністративної послуги; необхідність самостійно погоджувати документи в інших органах державної влади, органах місцевого самоврядування, а також пропозиції отримати адміністративну послугу через посередників за додаткову плату, що $\epsilon$ прямим порушенням норм Закону України «Про адміністративні послуги». У перспективах подальшого реформування системи адміністративних послуг з метою поліпшення якості їх надання вбачається за необхідне: 1) привести законодавство в усіх сферах державного управління, що стосуються надання послуг, у відповідність до вимог Закону України «Про адміністративні послуги»; 2) розробити стандарти якості адміністративних послуг i єдину методику для оцінювання їх надання; передбачити певну процедуру спрощення доступу громадян до адміністративних послуг, у т. ч. забезпечення належного інформування та консультування громадськості про порядок їх надання; 3) необхідно впорядкувати сферу оплати адміністративних послуг; 4) залучати громадські організації до проведення оцінки якості надання адміністративних послуг; 5) забезпечити прозоре висвітлення результатів проведеного моніторингу щодо надання послуг; 6) проводити аналіз зауважень і 
пропозицій суб’єктів звернень щодо якості надання адміністративних послуг; 7) проводити постійне навчання працівників центрів надання адміністративних послуг, співробітників органів виконавчої влади, котрі надають адміністративні послуги, у т. ч. 3 питань культури обслуговування громадян [6, с. 7-8].

В аспекті зазначених адміністративних послуг актуальним вважається застосування громадського контролю як одного 3 результативних механізмів покращення та виправлення недоліків у наданні адміністративних послуг. Через це під час здійснення громадського контролю варто зауважити на таких критеріях оцінки якості надання адміністративних послуг:

- визначений перелік публічних послуг, які надаються громадянам;

- встановлення обмежень щодо переліку публічних послуг ЦНАП відповідно до масштабів територіальних громад;

- добросовісне здійснення власних посадових зобов'язань працівниками ЦНАП відповідно до ухваленого положення та регламенту;

- укомплектовані картки надання публічних послуг i встановлення послідовності дій особи з метою їх одержання;

- відсутність ефекту копіювання адміністративних послуг;

- діяльність відповідно до графіка роботи, згідно з положеннями діючого законодавства;

- існування інформаційної сторінки в мережі «Інтернет», значний ступінь іiі інформативності;

- активне застосування електронних ресурсів для надання консультації, для прикладу, через застосуванням електронних ресурсів зв'язку чи за допомогою телефону;

- поширеність ЦНАП (функціонування значного числа денних центрів);

- встановлення переліку стендів 3 метою одержання населенням повних i грунтовних відомостей, які надає ЦНАП;

- застосування інформаційних технологій, для прикладу, функціонування інформаційних кіосків, через котрі можна одержати відомості про послуги центру надання адміністративних послуг;

- здійснення вчасної підготовки персоналу з належною кваліфікацією, змога підвищення кваліфікації, в разі потреби - проходження психологічної допомоги;

- забезпечення центрам надання адміністративних послуг умов для того, щоб громадяни могли попередньо записатися на прийом, застосовуючи інтернет чи телефон.

Висновки. Отже, грунтуючись на зазначеному вище, можна дійти висновку, що на даний час немає конкретно встановлених меж критеріїв якості надання адміністративних послуг, в результаті чого зумовлюється недостатня результативність роботи місцевих органів влади. Відтак варто зауважити, що 
введення системи оцінки критеріїв якості надання адміністративних послуг - це один із дієвих способів покращення ефективності органів місцевого самоврядування. Формулюючи оцінку якості надання адміністративних послуг, треба усвідомлювати, що головна іi ціль - це гарантування прав і свобод громадян, здійснення владних повноважень, що на рівні законодавства визначені за органами місцевого самоврядування. Щоб успішно впровадити процедури стосовно формулювання оцінки та якості надання адміністративних послуг, повинні існувати конкретно окреслені умови та алгоритм дій під час оцінки надання адміністративної послуги. Саме дана тематика може бути предметом подальших наукових розвідок.

\section{Лimepamypa:}

1. Бабінова О. Проблеми оцінки якості та ефективності діяльності органів місцевої влади. URL: http://www.niss.gov.ua/Monitor/September/6.htm.

2. Бригілевич I. Діяльність ЦНАП та оцінка якості надання адміністративних послуг: практичний посібник. URL: https://decentralization.gov.ua/uploads/library/file/15/Posibniik_CNAP.pdf.

3. Буренко Т. О. Актуальні підходи до оцінювання ефективності системи надання державних адміністративних послуг в Україні. Інвестиції : практика та досвід, 2011. № 9. $\quad$ С. 100-103.

4. Гудима Л. Особливості оцінювання якості надання адміністративних послуг, що надаються населенню органами місцевого самоврядування. URL http://dspace.wunu.edu.ua/ bitstream/316497/36259/1/381.pdf.

5. Смець А.В. Підвищення якості послуг органів виконавчої влади. Державне будівництво. 2007. № 2. URL :http://nbuv.gov.ua/UJRN/DeBu_2007_2_11.

6. Жук Ю.М. Надання адміністративних послуг населенню: орієнтація на якість. Теорія та практика державного управління. 2017. № 1 (56). С. 7-8.

7. Занфіров В.А. Критерії якості управлінських послуг публічної сфери. Держава та регіони. 2009. № 4. С. 35-40.

8. Карий О.I., Процак К.В. Маркетингові інструменти забезпечення якості надання адміністративних послуг. URL: http://science.lpnu.ua/sites/default/files/journal-paper/2019/apr/ 16466/semi12019-24-33.pdf.

9. Кириченко Ю.М. Особливості надання органами місцевого самоврядування адміністративних послуг. Право і суспільство. 2020. № 2. С. 151-156.

10. Маматова Т. Система надання адміністративних послуг в Україні: особливості нормативно-правового регулювання. Аспекти публічного управління. 2020. № 6. С. 164-177.

11. Про адміністративні послуги: Закон України від 06.09.2012 р. № 5203-VI. URL: http://zakon4.rada.gov.ua/laws/show/5203-17.

12. Про схвалення Концепції реформування місцевого самоврядування та територіальної організації влади в Україні: Розпорядження КМУ від 01.04.2014 № 333-p. URL: https://zakon.rada.gov.ua/go/333-2014-\%D1\%80.

13. Серант А., Огірко І. Оцінка якості надання адміністративних послуг. Ефективність державного управління. 2015. Вип. 42. С. 149-161.

14. Тимощук В. Надання адміністративних послуг у муніципальному секторі. Навчальний посібник для посадових осіб місцевого самоврядування. Асоціація міст України. К., ТОВ «ПІДПРИСМСТВО «ВІ ЕН ЕЙ», 2015. 124 с. 


\section{References}

1. Babinova, O. Problemy otsinky yakosti ta efektyvnosti diialnosti orhaniv mistsevoi vlady [Problems of assessing the quality and efficiency of local authorities]. Retrieved from http://www.niss.gov.ua/Monitor/September/6.htm [in Ukrainian].

2. Bryhilevych, I. Diialnist TsNAP ta otsinka yakosti nadannia administratyvnykh posluh [CNAP activities and assessment of the quality of administrative services]. Retrieved from https://decentralization.gov.ua/uploads/library/file/15/Posibniik_CNAP.pdf [in Ukrainian].

3. Burenko, T.O. (2011). Aktualni pidkhody do otsiniuvannia efektyvnosti systemy nadannia derzhavnykh administratyvnykh posluh $\mathrm{v}$ Ukraini [Current approaches to assessing the effectiveness of the system of public administrative services in Ukraine]. Investytsii : praktyka ta dosvid Investments: practice and experience, 9, 100-103 [in Ukrainian].

4. Hudyma, L. Osoblyvosti otsiniuvannia yakosti nadannia administratyvnykh posluh, shcho nadaiutsia naselenniu orhanamy mistsevoho samovriaduvannia [Features of assessing the quality of administrative services provided to the population by local governments]. Retrieved from http://dspace.wunu.edu.ua/bitstream/316497/36259/1/381.pdf [in Ukrainian].

5. Iemets, A.V. (2007). Pidvyshchennia yakosti posluh orhaniv vykonavchoi vlady [Improving the quality of services of executive bodies]. Derzhavne budivnytstvo - State building, 2. Retrieved from http://nbuv.gov.ua/UJRN/DeBu_2007_2_11 [in Ukrainian].

6. Zhuk, Yu.M. (2017). Nadannia administratyvnykh posluh naselenniu: oriientatsiia na yakist [Provision of administrative services to the population: focus on quality]. Teoriia ta praktyka derzhavnoho upravlinnia - Theory and practice of public administration, 1 (56), 7-8 [in Ukrainian].

7. Zanfirov, V.A. (2009). Kryterii yakosti upravlinskykh posluh publichnoi sfery [Criteria for the quality of public management services]. Derzhava ta rehiony - State and regions, 4, 35-40 [in Ukrainian].

8. Karyi, O.I. \& Protsak, K.V. Marketynhovi instrumenty zabezpechennia yakosti nadannia administratyvnykh posluh [Marketing tools to ensure the quality of administrative services]. Retrieved from http://science.lpnu.ua/sites/default/files/journal-paper/2019/apr/16466/semi12019-24-33.pdf [in Ukrainian].

9. Kyrychenko, Yu.M. (2020). Osoblyvosti nadannia orhanamy mistsevoho samovriaduvannia administratyvnykh posluh [Features of local self-government provision of administrative services]. Pravo $i$ suspilstvo - Law and society, 2, 151-156 [in Ukrainian].

10. Mamatova, T. Systema nadannia administratyvnykh posluh v Ukraini: osoblyvosti normatyvnopravovoho rehuliuvannia [The system of administrative services in Ukraine: features of legal regulation]. Aspekty publichnoho upravlinnia - Aspects of public administration, 6, 164-177 [in Ukrainian].

11. Zakon Ukrainy Pro administratyvni posluhy : pryiniatyi 06.09.2012 roku № 5203-VI [Law of Ukraine On administrative services activity from September 6 2012, № 5203-VI]. Retrieved from http://zakon4.rada.gov.ua/laws/show/5203-17 [in Ukrainian].

12. Rozporiadzhennia KMU Pro skhvalennia Kontseptsii reformuvannia mistsevoho samovriaduvannia ta terytorialnoi orhanizatsii vlady v Ukraini: pryiniate 01.04.2014 roku № 333-p [Order of the Cabinet of Ministers On approval of the Concept of reforming local self-government and territorial organization of power in Ukraine activity from April 1 2014, № 333-p]. Retrieved from https://zakon.rada.gov.ua/go/333-2014-\%D1\%80 [in Ukrainian].

13. Serant, A. \& Ohirko, I. Otsinka yakosti nadannia administratyvnykh posluh [Assessment of the quality of administrative services]. Efektyvnist derzhavnoho upravlinnia - Efficiency of public administration, 42, 149-161 [in Ukrainian].

14. Tymoshchuk, V. (2015). Nadannia administratyvnykh posluh u munitsypalnomu sektori [Provision of administrative services in the municipal sector]. Kyiv: TOV «PIDPRYIeMSTVO «VI EN EI» [in Ukrainian]. 